\title{
GSK-3 $\beta$, a double-edged sword in Nrf2 regulation: \\ Implications for neurological dysfunction and disease [version
}

\section{1; peer review: 2 approved]}

\author{
Megan Culbreth1, Michael Aschner (D)2
}

1Department of Environmental Medicine, University of Rochester School of Medicine and Dentistry, Rochester, NY, 14642, USA

${ }^{2}$ Department of Molecular Pharmacology, Albert Einstein College of Medicine, Bronx, NY, 10461, USA

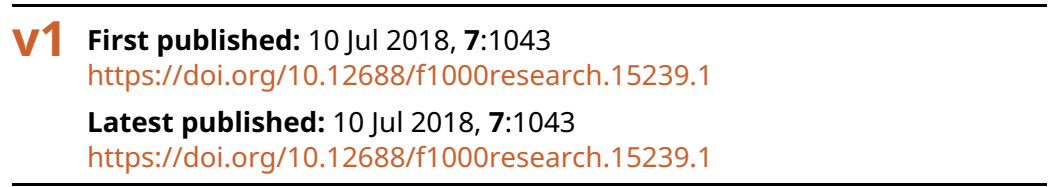

\section{Abstract}

In the past decade, it has become evident that glycogen synthase kinase $3 \beta$ (GSK-3 $\beta$ ) modulates the nuclear factor erythroid 2-related factor 2 (Nrf2) oxidative stress response. GSK-3 $\beta$ functions as an inhibitor, both directly in the activation and indirectly in the postinduction of Nrf2. The incidence of oxidative stress in neurological dysfunction and disease has made this signaling pathway an attractive therapeutic target. There is minimal evidence, however, to support a distinctive function for GSK-3 $\beta$ mediated Nrf2 inhibition in nervous system decline, apart from the typical oxidative stress response. In both Alzheimer's disease and brain ischemia, this pathway has been explored for potential benefits on disease etiology and advancement. Presently, it is unclear whether GSK-3 $\beta$ mediated Nrf2 inhibition markedly influences these disease states. Furthermore, the potential that each has unique function in neurodegenerative decline is unsubstantiated.

\section{Keywords}

GSK-3 $\beta$, Nrf2, oxidative stress

\section{Open Peer Review \\ Approval Status \\ 1 2 \\ version 1 \\ 10 Jul 2018
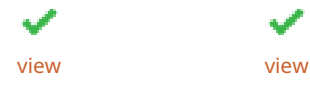 \\ 1. Masatake Fujimura, National Institute for Minamata Disease, Minamata, Japan \\ 2. Alexey Tinkov (D), Yaroslavl State University, Yaroslavl, Russian Federation \\ RUDN University, Moscow, Russian \\ Federation}

Any reports and responses or comments on the article can be found at the end of the article. 
Corresponding author: Michael Aschner (michael.aschner@einstein.yu.edu)

Author roles: Culbreth M: Conceptualization, Writing - Original Draft Preparation; Aschner M: Conceptualization, Supervision, Writing Review \& Editing

Competing interests: No competing interests were disclosed.

Grant information: MA has been supported in part by the National Institutes of Health (grant numbers NIEHS R01ES07331, NIEHS R01ES10563 and NIEHS R01ES020852).

The funders had no role in study design, data collection and analysis, decision to publish, or preparation of the manuscript.

Copyright: $₫ 2018$ Culbreth $\mathrm{M}$ and Aschner M. This is an open access article distributed under the terms of the Creative Commons Attribution License, which permits unrestricted use, distribution, and reproduction in any medium, provided the original work is properly cited.

How to cite this article: Culbreth M and Aschner M. GSK-3ß, a double-edged sword in Nrf2 regulation: Implications for neurological dysfunction and disease [version 1; peer review: 2 approved] F1000Research 2018, 7:1043

https://doi.org/10.12688/f1000research.15239.1

First published: 10 Jul 2018, 7:1043 https://doi.org/10.12688/f1000research.15239.1 


\section{Abbreviations}

Alzheimer's disease (AD), $\beta$-amyloid $(\mathrm{A} \beta)$, glycogen synthase kinase $3 \beta$ (GSK-3 $\beta$ ), middle cerebral artery occlusion and reperfusion (MCAO/R), nuclear factor erythroid 2-related factor 2 (Nrf2).

\section{Introduction}

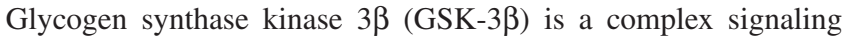
molecule, involved in a variety of cellular processes ${ }^{1}$. In the past decade, GSK-3 $\beta$ has been extensively investigated, particularly in regard to its role in neurological dysfunction and disease ${ }^{2,3}$. It is now evident GSK-3 $\beta$ participates in the cellular response to oxidative stress, a hallmark of several nervous system disorders. GSK-3 $\beta$ modulates this response through its interaction with nuclear factor erythroid 2-related factor $2(\mathrm{Nrf} 2)^{4,5}$. Although the GSK-3 $\beta-N r f 2$ association is well established, it has yet to be determined whether the dual regulatory nature of this interaction impacts disease advancement and potential therapies.

GSK-3 $\beta$ phosphorylates Nrf2, which results in its nuclear exclusion $^{6}$ and degradation ${ }^{4,7,8}$. Interestingly, this was demonstrated to occur in a kelch-like ECH-associated protein 1 (Keap1)independent manner ${ }^{4}$; however, active GSK-3 $\beta$ was induced by hydrogen peroxide ${ }^{6}$. Thus GSK-3 $\beta$ regulated Nrf2 activity possibly is oxidant-sensitive as well. GSK-3 $\beta$ has also been observed to indirectly modulate Nrf2 via Fyn phosphorylation. Fyn translocates to the nucleus resultant to GSK-3 $\beta$ phosphorylation, and in turn phosphorylates Nrf2, which stimulates its nuclear export ${ }^{5}$. It must be noted that none of the above-mentioned reports were conducted in neuronal models. Moreover, observed effects were in transiently transfected cells, and not on endogenous protein.

Despite limited evidence that GSK-3 $\beta$ regulates Nrf2 in a similar manner in the nervous system, this signaling pathway has emerged as an attractive therapeutic target for neurodegenerative diseases. Oxidative stress is a well-established feature of several cognitive disorders, including Alzheimer's disease (AD) and brain ischemia. However, a possible mechanism by which neurological dysfunction and disease modify GSK-3 $\beta$ mediated Nrf2 activity is unknown. Furthermore, the potential that this signaling axis contributes to disease etiology and progression has not been extensively explored.

Here, current research in AD and brain ischemia is highlighted with particular focus on potentially unique mechanisms by which these disorders modulate GSK-3 $\beta$ regulated Nrf2 activity.

\section{Alzheimer's disease}

GSK- $3 \beta$ is implicated in the advancement and potentially the etiology of AD. Extensive evidence corroborates its function in the learning and memory deficits observed in $\mathrm{AD}$ patients. Mechanistically, GSK-3 $\beta$ is linked to tau hyperphosphorylation and $\beta$-amyloid $(A \beta)$ deposition, significant markers of $\mathrm{AD}$ pathogenesis. Furthermore, it modifies the oxidative stress response resultant to $\mathrm{AD}$ progression ${ }^{3}$.

Recent reports have started to build connections between GSK$3 \beta$ and Nrf2 in AD pathology and propose prospective therapies.
GSK-3 $\beta$ suppression in a mouse model of AD was found to increase nuclear Nrf2 and total glutathione-S transferase (GST), an Nrf2 transcriptional target, in cortex. Moreover, reduced oxidative stress biomarkers and tau phosphorylation were observed $^{9}$. GSK-3 $\beta$ activation was also required for $\mathrm{A} \beta$-induced axonal transport deficits detected in primary hippocampal neurons. Tau presence was necessary for this outcome, but intriguingly was Fyn-independent ${ }^{10}$. Fyn phosphorylates tau ${ }^{11}$ and Nrf2. The latter requires GSK-3 $\beta$ activation ${ }^{5}$; however, GSK-3 $\beta$ directly phosphorylates $\mathrm{Nrf} 2$ as well ${ }^{6}$. Irrespectively, $\mathrm{Nrf} 2$ is excluded from the nucleus as a result ${ }^{5,6}$. Potential associations between GSK-3 $\beta$, Fyn, and Nrf2 were not demonstrated in this study ${ }^{10}$. Furthermore, the Fyn-independent nature of $\mathrm{A} \beta$ and tau in $\mathrm{AD}$ could underscore distinct mechanisms by which GSK-3 $\beta$ activation mediates disease advancement.

A new AD therapy, which simultaneously inhibits GSK-3 $\beta$ and induces $\mathrm{Nrf} 2$ has been proposed. Interestingly, therapeutic Nrf2 activation was found to be GSK-3 $\beta$ inhibition-independent in the in vitro $\mathrm{AD}$ model. However, the potentially distinct beneficial properties of GSK-3 $\beta$ inhibition and Nrf2 induction were not examined. Tested compounds exhibited enhanced neuroprotection and reduced oxidative stress $^{12}$. Similar to the reports mentioned above, this study did not connect GSK-3 $\beta$ inhibited Nrf2 activation to GSK-3 $\beta$ activated tau hyperphosphorylation and $\mathrm{A} \beta$ deposition.

Current research on $\mathrm{AD}$ pathology has only just begun to elucidate a possible association between GSK-3 $\beta$ activation and the Nrf2-mediated oxidative stress response. Existing data does not, however, clearly demonstrate that GSK-3 $\beta$ activation represses Nrf2 function in AD models. Theoretically, observed oxidative stress in $\mathrm{AD}$ could occur entirely independent of GSK-3 $\beta$. Moreover, other stress response factors apart from Nrf2 might be involved.

\section{Ischemia}

GSK-3 $\beta$ has also emerged as a target in the treatment of brain ischemia. However, distinct from $\mathrm{AD}$, recent studies have focused on GSK-3 $\beta$ regulation of Nrf2 in this disease state. Also unlike $\mathrm{AD}$, an altered oxidative environment is the primary feature of brain ischemia, and not simply a secondary factor in the disease.

Existing evidence indicates GSK-3 $\beta$ inhibition enhances Nrf2 activity in the rat cerebral cortex following middle cerebral artery occlusion and reperfusion (MCAO/R). Interestingly, however, this brain ischemia model did not exhibit increased active GSK-3 $\beta$ and decreased nuclear Nrf2 simply as a consequence of MCAO/R. Furthermore, Nrf2 bound at the antioxidant response element (ARE) and subsequent target gene expression was only enhanced following $\mathrm{MCAO} / \mathrm{R}$ in the presence of GSK-3 $\beta$ inhibitors ${ }^{13}$. These data potentially imply GSK-3 $\beta$ regulation of Nrf2 is not directly involved in brain ischemia. Moreover, this study did not demonstrate improvement in the rat cerebral cortex following $\mathrm{MCAO} / \mathrm{R}$ resultant to GSK-3 $\beta$ inhibition and Nrf2 activation.

Another report, however, did validate a GSK-3 $\beta$ inhibitor in an acute ischemia rat model, displaying reduced infarct volume, brain 
edema, and neurological deficit. These improvements were correlated with increased total $\mathrm{Nrf} 2$ protein and heme-oxygenase. Curiously, however, recovery was only examined 24 hours post-MCAO ${ }^{14}$, whereas the article mentioned above showed GSK-3 $\beta$ inhibition effects as early as 6 hours post-MCAO ${ }^{13}$. The timescale by which GSK-3 $\beta$ inhibitors exhibit therapeutic properties in brain ischemia must be further examined.

Present knowledge does not indicate brain ischemia directly alters GSK-3 $\beta$ regulation of Nrf2. Active GSK-3 $\beta$ is not enhanced in ischemia models, and Nrf2 downregulated as a consequence. Intriguingly, however, GSK-3 $\beta$ inhibitors do render improvement in these models, although evidence that Nrf2 is involved in this response is minimal. Possibly, GSK-3 $\beta$ inhibitors act on another signaling pathway in which GSK-3 $\beta$ is involved.

\section{Conclusion}

The current body of evidence available to support a primary role for GSK-3 $\beta$ regulation of Nrf2 in neurological dysfunction and disease is incomplete. There is little to substantiate that this signaling axis is modulated differently under nervous system distress relative to a typical endogenous oxidative stress response. Moreover, the potentially distinct functions of GSK-3 $\beta$ and Nrf2 in cognitive disorders have not been linked to their possible combinatorial roles.

Polymorphisms in both the GSK-3 $\beta^{15}$ and Nrf2 $2^{16}$ gene promoter sequences have been associated with the onset of neurodegenerative diseases. There is no data, however, to validate that these polymorphisms impact the function of the GSK-3 $\beta$ and Nrf2 signaling pathway.

Future studies should focus on the distinctive functions for GSK-3 $\beta$ and Nrf2 in neurological dysfunction and disease. Based on these unique roles, potential links to their effects on each other should be formulated. Without these efforts, there is minimal evidence to substantiate a causative function for this signaling axis on cognitive disorder apart from an oxidative stress response.

\section{Data availability}

No data are associated with this article.

\section{Competing interests}

No competing interests were disclosed.

\section{Grant information}

MA has been supported in part by the National Institutes of Health (grant numbers NIEHS R01ES07331, NIEHS R01ES10563 and NIEHS R01ES020852).

The funders had no role in study design, data collection and analysis, decision to publish, or preparation of the manuscript.
1. Grimes CA, Jope RS: The multifaceted roles of glycogen synthase kinase 3beta in cellular signaling. Prog Neurobiol. 2001; 65(4): 391-426. PubMed Abstract | Publisher Full Text

2. Golpich $M$, Amini E, Hemmati $F$, et al:: Glycogen synthase kinase-3 beta (GSK3B) signaling: Implications for Parkinson's disease. Pharmacol Res. 2015; 97: $16-26$.

PubMed Abstract | Publisher Full Text

3. Hooper C, Killick R, Lovestone S: The GSK3 hypothesis of Alzheimer's disease. $J$ Neurochem. 2008; 104(6): 1433-9.

PubMed Abstract | Publisher Full Text | Free Full Text

4. Rada P, Rojo AI, Chowdhry S, et al.: SCF/\{beta\}-TrCP promotes glycogen synthase kinase 3-dependent degradation of the Nrf2 transcription factor in a Keap1-independent manner. Mol Cell Biol. 2011; 31(6): 1121-33. PubMed Abstract | Publisher Full Text | Free Full Text

5. Jain AK, Jaiswal AK: GSK-3beta acts upstream of Fyn kinase in regulation of nuclear export and degradation of NF-E2 related factor 2. J Biol Chem. 2007; 282(22): 16502-10.

PubMed Abstract | Publisher Full Text

6. Salazar M, Rojo Al, Velasco D, et al.: Glycogen synthase kinase-3beta inhibits the xenobiotic and antioxidant cell response by direct phosphorylation and nuclear exclusion of the transcription factor Nrf2. J Biol Chem 2006; 281(21): 14841-51.

PubMed Abstract | Publisher Full Text

7. Rada P, Rojo Al, Evrard-Todeschi N, et al.: Structural and functional characterization of Nrf2 degradation by the glycogen synthase kinase 3/ק-TrCP axis. Mol Cell Biol. 2012; 32(17): 3486-99.

PubMed Abstract | Publisher Full Text | Free Full Text

8. Chowdhry S, Zhang $\mathrm{Y}, \mathrm{McMahon} \mathrm{M}$, et al:: Nrf2 is controlled by two distinct $\beta$ TrCP recognition motifs in its Neh6 domain, one of which can be modulated by GSK-3 activity. Oncogene. 2013; 32(32): 3765-81.

PubMed Abstract | Publisher Full Text | Free Full Text
9. Farr SA, Ripley JL, Sultana R, et al.: Antisense oligonucleotide against GSK$3 \beta$ in brain of SAMP8 mice improves learning and memory and decreases oxidative stress: Involvement of transcription factor Nrf2 and implications for Alzheimer disease. Free Radic Biol Med. 2014; 67: 387-95. PubMed Abstract | Publisher Full Text | Free Full Text

10. Vossel KA, Xu JC, Fomenko V, et al.: Tau reduction prevents $A \beta$-induced axonal transport deficits by blocking activation of GSK3ß. J Cell Biol. 2015; 209(3): 419-33. PubMed Abstract | Publisher Full Text | Free Full Text

11. Lee G, Thangavel R, Sharma VM, et al:: Phosphorylation of tau by fyn: implications for Alzheimer's disease. J Neurosci. 2004; 24(9): 2304-12. PubMed Abstract | Publisher Full Text

12. Gameiro I, Michalska P, Tenti G, et al:: Discovery of the first dual GSK3B inhibitor/Nrf2 inducer. A new multitarget therapeutic strategy for Alzheimer's disease. Sci Rep. 2017; 7: 45701.

PubMed Abstract | Publisher Full Text | Free Full Text

13. Chen $X$, Liu $Y$, Zhu J, et al: GSK-3 $\beta$ downregulates Nrf2 in cultured cortical neurons and in a rat model of cerebral ischemia-reperfusion. Sci Rep. 2016; 6 : 20196.

PubMed Abstract | Publisher Full Text | Free Full Text

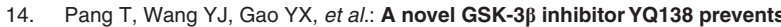
neuronal injury induced by glutamate and brain ischemia through activation of the Nrf2 signaling pathway. Acta Pharmacol Sin. 2016; 37(6): 741-52. PubMed Abstract | Publisher Full Text | Free Full Text

15. Mateo I, Infante J, Llorca J, et al.: Association between glycogen synthase kinase-3beta genetic polymorphism and late-onset Alzheimer's disease. Dement Geriatr Cogn Disord. 2006; 21(4): 228-32. PubMed Abstract | Publisher Full Text

16. von Otter M, Bergström P, Quattrone A, et al:: Genetic associations of Nrf2encoding NFE2L2 variants with Parkinson's disease - a multicenter study. BMC Med Genet. 2014; 15: 131.

PubMed Abstract | Publisher Full Text | Free Full Text 


\title{
Open Peer Review
}

\section{Current Peer Review Status:}

\section{Version 1}

Reviewer Report 19 July 2018

https://doi.org/10.5256/f1000research.16599.r35941

(c) 2018 Tinkov A. This is an open access peer review report distributed under the terms of the Creative Commons Attribution License, which permits unrestricted use, distribution, and reproduction in any medium, provided the original work is properly cited.

\author{
Alexey Tinkov \\ 1 Yaroslavl State University, Yaroslavl, Russian Federation \\ 2 RUDN University, Moscow, Russian Federation
}

The manuscript provides interesting data on the role of GSK-3b-Nrf2 interplay in neurological diseases. Although the authors review the existing data in relation to Alzheimer's disease and ischemic stroke, the mechanism may play a significant role in other disorders. It is also of particular interest whether this mechanism may be involved in mercury neurotoxicity, especially in view of the earlier study by the authors $\left({ }^{1}\right)$.

Only minor changes may be recommended:

It is recommended to add a reference to the sentence in the Introduction "Oxidative stress is a well-established feature of several cognitive disorders, including Alzheimer's disease (AD) and brain ischemia"

I suppose that the chemical nature of the compound family should be mentioned $(2,4-$ dihydropyrano[2,3-c]pyrazoles)

\section{References}

1. Culbreth M, Zhang Z, Aschner M: Methylmercury augments Nrf2 activity by downregulation of the Src family kinase Fyn.Neurotoxicology. 2017; 62: 200-206 PubMed Abstract | Publisher Full Text

\section{Is the topic of the review discussed comprehensively in the context of the current literature?}

Yes

\section{Are all factual statements correct and adequately supported by citations?}

Yes

Is the review written in accessible language?

Yes 
Are the conclusions drawn appropriate in the context of the current research literature? Yes

Competing Interests: No competing interests were disclosed.

I confirm that I have read this submission and believe that I have an appropriate level of expertise to confirm that it is of an acceptable scientific standard.

Reviewer Report 13 July 2018

https://doi.org/10.5256/f1000research.16599.r35943

(C) 2018 Fujimura M. This is an open access peer review report distributed under the terms of the Creative Commons Attribution License, which permits unrestricted use, distribution, and reproduction in any medium, provided the original work is properly cited.

\section{Masatake Fujimura}

Department of Basic Medical Sciences, National Institute for Minamata Disease, Minamata, Japan

I am very interested in this report. This article was well written without any over discussion. Although the roles of GSK-3beta on neurological disease were well investigated for long time, that was not fully resolved at this time. Authors indicated the possibility that GSK-3beta modified the state of neurological disease through the regulation of Nfr2. In this regard, however, authors only mentioned Alzheimer's disease and ischemia among neurological diseases. I hope that they discussed the roles of GSK-3beta through the regulation of $\mathrm{Nfr} 2$ in other neurological disease.

Is the topic of the review discussed comprehensively in the context of the current literature?

Partly

Are all factual statements correct and adequately supported by citations? Partly

Is the review written in accessible language?

Yes

Are the conclusions drawn appropriate in the context of the current research literature? Yes

Competing Interests: No competing interests were disclosed.

Reviewer Expertise: Neurotoxicology, Neuropharmacology

I confirm that I have read this submission and believe that I have an appropriate level of expertise to confirm that it is of an acceptable scientific standard. 
The benefits of publishing with F1000Research:

- Your article is published within days, with no editorial bias

- You can publish traditional articles, null/negative results, case reports, data notes and more

- The peer review process is transparent and collaborative

- Your article is indexed in PubMed after passing peer review

- Dedicated customer support at every stage

For pre-submission enquiries, contact research@f1000.com 